\title{
Thoughts of Secondary, High School and University Students about Unwanted and Violent Behaviors in Sports
}

\author{
Levent Var ${ }^{1, *}$, Bekir Barıș Cihan² \\ ${ }^{1}$ School of Physical Education and Sports, Kirsehir Ahi Evran University, Turkey \\ ${ }^{2}$ School of Physical Education and Sports, Yozgat Bozok University, Turkey
}

Copyright $\odot 2019$ by authors, all rights reserved. Authors agree that this article remains permanently open access under the terms of the Creative Commons Attribution License 4.0 International License

\begin{abstract}
In this study, it was aimed to determine the opinions of middle school, high school and university students about the unwanted and violent behaviors in sports. A total of 784 students (330 females, 454 males) studying in Kirsehir in 2017-2018 academic year participated in the study. A questionnaire consisting of two parts was developed by Şeker [1] in order to determine the students' thoughts about unwanted behaviors and violence in sports. SPSS 22.0 package program was used for statistical analysis of the obtained data and results were evaluated at $\mathrm{p}<0.05$ significance level. Frequency analysis and One-Way ANOVA analysis were performed in the research. When students' ideas about sports and violent behaviors in sports are examined according to their educational level, there were unwanted behaviors in sports. There was meaningfulness found between secondary and high school students, 000 ( $p$ $<0.001$ ) between secondary and university students, 001 ( $\mathrm{p}<0.01)$ level and with violent behaviors in sports between secondary and university students at $001(\mathrm{p}<0.01)$ level meaningfulness detected.
\end{abstract}

Keywords Unwanted Behaviors, Violent, Sports, Students

\section{Introduction}

Sports, which is one of the most common and effective social institutions of today's modern society, is a popular entertainment tool that is at the center of society and which is highly valued and drives the masses.

Nowadays, when the definition of sport is done, it can be mentioned that the sport removes or alleviates more aggression and anger explosions. On the other hand, the number and severity of aggressive behaviors increased in many sports events [2]. It is an obvious excessive use of physical force that causes violence, damage, or destruction [3] as a result of a combination of many factors that interact in a very complex way [4].

The sport, which is associated with all units of society, is within social life, and the characteristics of society are reflected in sports. The individual interacting with the community is part of the society he lives in and is affected by the events around him. All negative factors that an individual may encounter in this relationship pattern can lead to undesirable behaviors. In most parts of our daily life, we may encounter undesirable behaviors, and we may face with some undesirable behaviors in sports. It is an expected result that the unwanted and violent behaviors experienced in other areas of social life negatively affect the sport.

One of the environments in which the individual of education age spends most time is the school. The school provides multi-faceted social support to the individual and takes them from society, prepares them for the future and offers them to the society again. One of the functions of the school is to prepare a clean environment by eliminating the harmful properties that exist in the environment [5]. While the school is trying to create a clean environment, unfortunately, there are unwanted student behaviors in and out of schools.

Violent student behaviors are included in these behaviors [6]. The most observed undesirable and violent behaviors in schools are; individual or mass struggle, moving a knife or similar cutting tool, pushing a friend, naming, mocking, saying bad words, insulting, swearing, discussion, damaging the school supplies, threatening [7]. The school should attach importance to moral and human values and making studies to keep individuals away from such behaviors [8]. It is because children and young people can learn positive behaviors if they can learn negative behaviors [9].

The risk factors that increase the likelihood of the young person or the child to show unwanted and violent behaviors 
can be summarized in four groups as social, familial, school-related and individual factors [10]. By analyzing these risk factors well by the experts in their fields, changing the point of view of the unwanted and violent behaviors of the individuals in the desired direction by correcting the negativities in these factors can reduce the frequency of these behaviors both in society and in sports. It may also contribute positively to the opinions of individuals about unwanted and violent behaviors experienced in sports.

In the light of this information, the aim of this study is to determine the students' perspectives on the unwanted and violent behaviors experienced in sports and sports and to present their suggestions about the negative behaviors of the students in sports field.

\section{Materials and Methods}

This section presents; information about the model of the study, the study group, data collection and analysis.

\subsection{Research Model}

This research is a descriptive model. The survey model aims to present a situation in the past or present [11]. In this study, it is aimed to reveal the opinions of students about behaviors and behaviors of violent behaviors in sports and to examine them in terms of some variables.

\subsection{Study Group}

The study group of the study consisted of 784 students (330 females and 454 males) who were studied in middle school, high school and university levels in 2017-2018 academic year in Kirsehir. 172 of the students are secondary school, 324 are high school, 288 students are at university.

\subsection{Collection of Data}

A survey consisted of two parts was developed by Şeker [1] used in order to determine the students' opinions about unwanted behaviors and violence in sports. In the first part of the questionnaire, the personal information form used to determine the demographic characteristics of the students and the second part of the questionnaire consist of questions prepared to determine the students' opinions about the undesired behaviors and violence in sports. Students answer these questions as "yes". The reliability of the data collection tool for this research group has been re-checked and the Cronbach Alpha internal consistency test has the reliability coefficient (Cronbach's Alpha value) of questions related to unwanted behaviors in sport. The reliability coefficient (Cronbach's Alpha value) of the questions related to violent behaviors in sport was determined as 0,82 .

\subsection{Statistical Analysis}

SPSS 22.0 package program was used for statistical analysis of the obtained data and results were evaluated at $\mathrm{p}$ $<0.05$ significance level. The normality test was applied to determine if the data were in accordance with normal distribution. Since the number of athletes (784) was higher than 30, Kolmogorov-Smirnov table [12]. According to Kolmogorov-Smirnov; variables are normally distributed ( $p>0.05$ ). Therefore, parametric test was applied to the variables. Demographic structure of the students participating in the study (Table 1), the students participating in the research (Table 2) and sports violence (Table 3) determine the views of the behavior related to violence (Table 3) frequency analysis, sports behaviors and violent behavior in sport according to the level of education (secondary school, high school and university) One-Way ANOVA analysis (Table 4) applied. 
Table 1. Frequency analyses of students

\begin{tabular}{|c|c|c|c|c|c|c|c|}
\hline & \multicolumn{7}{|c|}{ Education Levels } \\
\hline & \multicolumn{3}{|c|}{$\begin{array}{c}\text { Secondary } \\
(N=172-\%=21.9)\end{array}$} & \multicolumn{2}{|c|}{$\begin{array}{c}\text { High school } \\
(n=324-\%=41.3)\end{array}$} & \multicolumn{2}{|c|}{$\begin{array}{c}\text { University } \\
(n=288-\%=36.7)\end{array}$} \\
\hline & & f & $\%$ & f & $\%$ & $\mathbf{f}$ & $\%$ \\
\hline \multirow{2}{*}{ Gender } & Female & 86 & 50,0 & 140 & 43,2 & 104 & 36,1 \\
\hline & Male & 86 & 50,0 & 184 & 56,8 & 184 & 63,9 \\
\hline \multirow{2}{*}{ Do you support a team? } & Yes & 158 & 91,9 & 288 & 88,9 & 252 & 87,5 \\
\hline & No & 14 & 8,1 & 36 & 11,1 & 36 & 12,5 \\
\hline \multirow{4}{*}{$\begin{array}{l}\text { How fanatic are you as a supporter of your } \\
\text { team? }\end{array}$} & Never & 20 & 11,6 & 58 & 17,9 & 40 & 13,9 \\
\hline & Little & 42 & 24,4 & 102 & 31,5 & 96 & 33,3 \\
\hline & Average & 68 & 39,5 & 100 & 30,9 & 88 & 30,6 \\
\hline & Very Much & 42 & 24,4 & 64 & 19,8 & 64 & 22,2 \\
\hline \multirow{2}{*}{ Do you watch sports competitions? } & Yes & 114 & 66,3 & 234 & 72,2 & 208 & 72,2 \\
\hline & No & 58 & 33,7 & 90 & 27,8 & 80 & 27,8 \\
\hline \multirow{2}{*}{ Do you follow sports media? } & Yes & 72 & 41,9 & 182 & 56,2 & 180 & 62,5 \\
\hline & No & 100 & 58,1 & 142 & 43,8 & 108 & 37,5 \\
\hline
\end{tabular}

Table 2. Frequencies of Thoughts of Students that show participation to the unwanted behaviors in sports

\begin{tabular}{|c|c|c|c|c|c|c|c|c|c|}
\hline \multirow{3}{*}{$\begin{array}{l}\text { QUESTIONS RELATED TO THE UNWANTED } \\
\text { BEHAVIOURS IN SPORTS }\end{array}$} & & \multicolumn{8}{|c|}{ Education Levels } \\
\hline & & \multicolumn{2}{|c|}{ Secondary } & \multicolumn{2}{|c|}{ High school } & \multicolumn{2}{|c|}{ University } & \multicolumn{2}{|c|}{ GENERAL } \\
\hline & & $\mathrm{f}$ & $\%$ & f & $\%$ & $\mathrm{f}$ & $\%$ & $\mathrm{f}$ & $\%$ \\
\hline \multirow{2}{*}{$\begin{array}{l}\text { Do you think it is appropriate for fans to throw unwanted } \\
\text { matter on the field? }\end{array}$} & Yes & 24 & 14,0 & 18 & 5,6 & 12 & 4,2 & 54 & 7,93 \\
\hline & No & 148 & 86,0 & 306 & 94,4 & 276 & 95,8 & 730 & 92,07 \\
\hline \multirow{2}{*}{ Do you think it is appropriate for athletes to bet? } & Yes & 32 & 18,6 & 54 & 16,7 & 28 & 9,7 & 114 & 15,00 \\
\hline & No & 140 & 81,4 & 270 & 83,3 & 260 & 90,3 & 670 & 85,00 \\
\hline \multirow{2}{*}{$\begin{array}{l}\text { Do you find it appropriate for athletes to cheat to win the } \\
\text { match? }\end{array}$} & Yes & 16 & 9,3 & 22 & 6,8 & 16 & 5,6 & 54 & 7,23 \\
\hline & No & 156 & 90,7 & 302 & 93,2 & 272 & 94,4 & 730 & 92,77 \\
\hline \multirow{2}{*}{$\begin{array}{l}\text { Do you think it would be appropriate events of match } \\
\text { fixing in sports in terms of Fair-Play? }\end{array}$} & Yes & 18 & 10,5 & 14 & 4.3 & 10 & 3,5 & 42 & 5,4 \\
\hline & No & 154 & 89,5 & 310 & 95,7 & 278 & 96,5 & 742 & 94,6 \\
\hline \multirow{2}{*}{ Do you think it is appropriate for athletes to use doping? } & Yes & 24 & 14,0 & 40 & 12,3 & 36 & 12,5 & 100 & 12,93 \\
\hline & No & 148 & 86,0 & 284 & 87,7 & 252 & 87,5 & 684 & 87,07 \\
\hline
\end{tabular}

\section{Results}

Totally 784 students, 330 female and 454 male, participated in the study. $21.9 \%$ of the participants were secondary school students, $41.3 \%$ were high school students and $36.7 \%$ were university students. It is seen that $89 \%$ of the students support a team and $11 \%$ do not support a team. $11 \%$ of the secondary school students are not fanatical, $42 \%$ are very fanatic, $17.9 \%$ of high school students are not fanatical, $19.8 \%$ are very fanatical, $13.9 \%$ of university students are not fanatical. And $22.2 \%$ are very fanatical. $66.3 \%$ of secondary school students, $72.2 \%$ of high school students, $72.2 \%$ of university students watching sports events, $33.7 \%$ of secondary school students, $27.8 \%$ of high school students, $\% 27.8$ of university students 27.8 of them do not watch sports events. $41.9 \%$ of secondary school students, $56.2 \%$ of high school students, $62.5 \%$ of university students are observed to follow sports media.

When Table 2 is examined, it is seen that most of the 
students who participated in the research did not generally find wrong behaviors in sports. According to these findings, it can be said that students do not accept unwanted behaviors in sports as their level of education increases.

When Table 3 is examined, it can be said that most of the students who participated in the research did not find the behaviors that involve violence in general. $7,70 \%$ of the students did not find it appropriate to act aggressively against their team because of the failure of the team. But $26.73 \%$ of the students objected aggressively to the referee as a result of the referee's wrong decisions and $23.77 \%$ of the referee on the grounds that their decisions were inaccurate, it was found that the fans were able to react aggressively to the referee. According to these findings, it can be said that students do not accept violent behaviors in sports as their education level increases.

Table 3. Frequencies of Thoughts of Students that show participation to the unwanted behaviors in sports

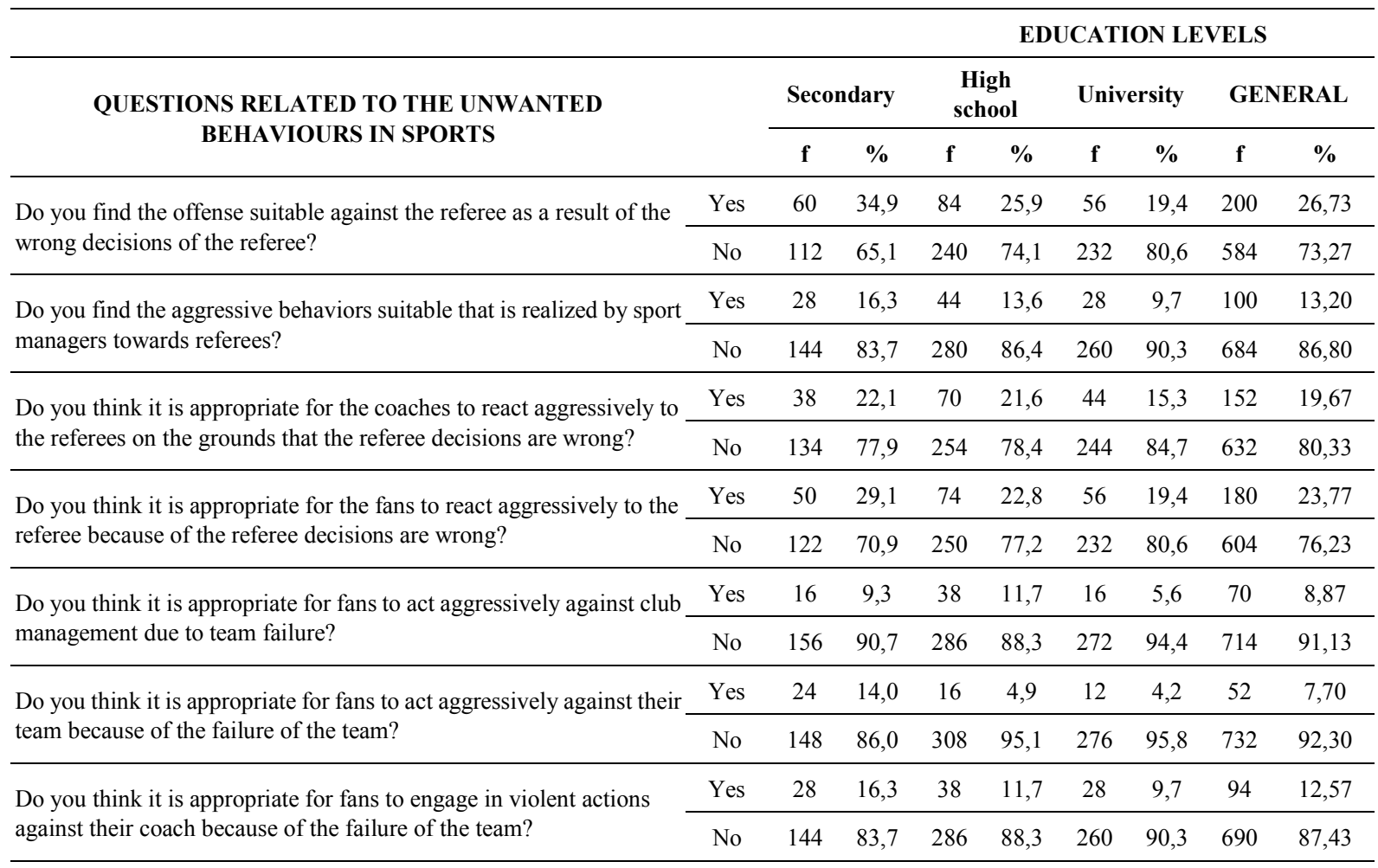

Table 4. Comparison of unwanted behaviors in sports and violence behaviors in sports according to students' education levels (According to Total Points)

\begin{tabular}{|c|c|c|c|c|c|}
\hline Dependent Variables & Educat & & Average Difference & Std. Error & p. \\
\hline \multirow{6}{*}{ Unwanted Behaviors in Sports } & \multirow{2}{*}{ Secondary } & High school &,$- 41143^{*}$ & ,09987 &, $000^{* * * *}$ \\
\hline & & University &,$- 38211^{*}$ & ,10201 &, $001^{* *}$ \\
\hline & \multirow{2}{*}{ High school } & Secondary &, $41143^{*}$ & ,09987 &, $000^{* * *}$ \\
\hline & & University &, 02932 &, 08573 & ,938 \\
\hline & \multirow{2}{*}{ University } & Secondary & ,38211* &, 10201 &, $001 * *$ \\
\hline & & High school &,- 02932 &, 08573 & ,938 \\
\hline \multirow{6}{*}{ Violence Behaviors in Sports } & \multirow{2}{*}{ Secondary } & High school &,- 29515 &, 16249 &, 165 \\
\hline & & University &,$- 58527^{*}$ &, 16598 &, $001^{* *}$ \\
\hline & \multirow{2}{*}{ High school } & Secondary & ,29515 &, 16249 &, 165 \\
\hline & & University &,- 29012 &, 13949 & ,095 \\
\hline & \multirow{2}{*}{ University } & Secondary &, $58527^{*}$ &, 16598 &, $001^{* *}$ \\
\hline & & High school & ,29012 & ,13949 & ,095 \\
\hline
\end{tabular}

${ }^{* *} \mathrm{p}<0,01 \quad{ }^{* * *} \mathrm{p}<0,001$


In Table 4, when the behaviors and behaviors of violent behaviors in sports are analyzed according to their total levels (middle school, high school and university); Unwanted behaviors in sports; between secondary school and high school students, $000(\mathrm{p}<0.001)$ and between middle school and university students, 001 ( $\mathrm{p}$ $<0.01)$ level of significance was determined.

Violence in sports was found significant result between secondary school and university students at $001(\mathrm{p}<0.01)$ level.

\section{Discussion and Conclusions}

784 students attended in this study, which was conducted to determine the opinions of students about unwanted and violent behaviors in sports. It was determined that a large part of the students were teamed up and followed by sports competitions, more than $50 \%$ of them followed sports media, and secondary school students were more fanatical than other students.

It is seen that most of the students who participated in the research did not find the undesirable behaviors in sports in general. Şebin at al. [13] examined the views of university students about the fairplay, athletes should be obeyed the rules of the game, referee decisions should be complied with, the rules of the game is more important than winning and win the opponent to be injured if necessary cannot give up the win. It is stated that students' opinions about undesirable behaviors in sports are positive. This study supports the results of our study.

The violent behavior in sport a large portion of the students surveyed said they find the right overall. According to the study done by Gençay \& Karaküçük [14], the results showed that students become more familiar with their team as their age get younger, they did not want to see violence in sports and behave in accordance with fair-play approach. These results are in quality of supporting ours. Aydin et al. [15] investigated secondary school students' tendency to violence, doing active sport or not. They reported there were no significant differences between students' tendency to violence according to their ages and sport participation situations, on the other hand there were significant differences according to their class and perceived success in class. This study showed that class and perceived success in class are predictors of tendency to violence.

According to the results of the research, $26.73 \%$ of the students were violent in sports; As a result of wrong decisions made by the athlete against the referee and the aggressive objection to the referee; $23.77 \%$ of them found suitable and say "it is an offensive denial to the referee as a result of the wrong decisions of the referee". In the study of Başaran et al. [16] examined students' understanding of fair play, only $18.8 \%$ of the students have reached the finding that "I do not lose my respect for the referee even when he made an incorrect decision". According to this finding most of the students show big reactions to the wrong decisions of the referee. Reyhan [17], found in the study, $35.1 \%$ of the students participating in the research, athletes, as a result of the wrong decisions of the referee to aggressive objection to the referee was found as proper. These results support our research results.

When the body of the literature is examined, it is seen that the referee decisions in many studies are effective in the violence and aggression behaviors experienced in sports. Thus, in order to increase the qualifications of the referees, it can be thought that the necessary studies should be carried out by the refereed institutions. However, athletes, coaches and spectators must respect the referee's decisions and help the judges make the right decisions. Yildiran [18] emphasized that in order to avoid unwanted behaviors in sports; one should respect for rules, equality of opportunity, avoiding unfair advantages and respecting the referee authority.

By enhancing the active participation of students with fair play practices, the number of undesired behaviors will be reduced and there will be a small increase in the number of useful behaviors at the end of the practices [19]. In study of Pilz [20], sports in the undesirable behaviors of people that they perceive the tactical necessity, the development of sportsmanship activities should be redirected to schools, primary and secondary school children and young people. Gessmann [21] thinks that sports education has an increasing impact on school sports and physical education, especially in the 70s, and that physical education courses cannot adequately guarantee the behavior of Fair Play [18]. In order to raise a youth with ethical characteristics, starting from physical education classes of primary and secondary school children, the athlete, coach, sportsman, referee, author and audience of the future are important in terms of the fact that they will emerge from this mass. It is thought that giving great importance to education and long-term effective training [22] will be impressive in reducing unwanted behaviors in sports.

Within the scope of efforts to create awareness about sport's ethical values and to carry out the necessary structural changes, physical education courses and lack of inter-school education necessitate the use of a suitable environment for gaining and exhibiting appropriate behaviors in Fair Play [23]. Bailey [24] explored the scientific evidence that has been gathered on the contributions and benefits of physical education and sport (PES) in schools for both children and for educational systems. He stressed that many of these benefits will not necessarily result from participation and the effects are likely to be mediated by the nature of the interactions between students and their teachers, parents, and coaches who work with them [24].

As a result, the findings of this study indicate that students' opinions about unwanted and violent behaviors in 
sports are highly positive. It is seen that students differ significantly according to education level variables. Although the views of the students are positive, students should be more conscious to implement these ideas and make them happen, as well as to minimize the negative and undesired behaviors experienced in sports. In this context, the responsibility of parents, teachers and coaches is great. It should be emphasized that the sporting environments are competing areas where skills are competed, no one should do undesired behaviors in these races, the necessity of showing suitable behaviors by spectators and to be honest is more important than winning.

\section{REFERENCES}

[1] Şeker, R. (2011). Examination of high school and university level young people's views on violence and undesirable behaviors in sport. Unpublished Master Thesis, Kahramanmaraș Sütçü İmam University, Institute of Health Sciences, Kahramanmaraş.

[2] Baumann, S. (1994). Applied Sports Psychology. Alfa Printing and Publishing House Istanbul.

[3] Mutza, M., Jürgen, B. (2009). The role of sports for violence. International Journal of Sport Policy. 1 (3): 305-321.

[4] Coakley, J. (2014). Sports in society: Issues and controversies. McGraw-Hill Higher Education.

[5] Tezcan, M (1994). Sociology of Education. 9.Print, Summit Offset, Ankara.

[6] Freedman, J. L., Sears, D.O. and Carlsmith, J.M. (1989). Social Psychology. (Translated by: Ali Dönmez), Ara Publishing, Istanbul.

[7] Di Canio, M. (1993). Classroom Violence, The Encyclopedia of Violence: Origins, Attitudes, Consequences. New York: Facts on File.

[8] Çakır, H. İ. (2014) Examination of aggression status of athletes participating in high school competitions (example of Rize province). Unpublished Master's Thesis, Dumlupınar University, Kütahya.

[9] Weidner, J., Kilb, R. (Eds.). (2010). Konfrontative Pädagogik: Konfliktbearbeitung in Sozialer Arbeit und Erziehung. Springer-Verlag.

[10] Morrison, G. M., Furlong, M. J., and Morrison, R. L. (1994). School violence to school safety. School Psychology Review, 23 (2): 236-256.

[11] Karasar, N. (2015). Scientific Research Method. Nobel Publications. Ankara.

[12] Alpar, R. (1997). Introduction To Applied Multivariate Statistical Methods-I. Bağırgan Publishing House. Ankara.

[13] Şebin, K., Tozoğlu, E., Yilmaz, S., Demirel, N., Bostanci, O. (2007). University students who play sports. Journal of Physical Education and Sport Sciences, 9 (2).
[14] Gençay, S., Karaküçük, S. (2006). Research on University Students' Behaviors Regarding Sports Fans. Gazi Journal of Physical Education and Sport Sciences, 11 (4), 11-22.

[15] Aydın, P., Ersoy, A., \& Aktaş, N. (2015). Examining 12-14 age secondary school students' tendency to violence doing active sport or no. Sportive Sight: Journal of Sports and Education. 2 (1), 1-9.

[16] Başaran, Z., Erdogan, R. B., Körmükçü, Y., Adalı, H. (2017). Investigation of Fair-Play Understanding of Students of Physical Education and Sports School. Journal of Physical Education and Sports Studies, 9 (1), 35-43.

[17] Reyhan, S., (2016). The comparison of the views of university students on violence and undesirable behaviors in sports (Siirt University, School of Physical Education and Sports), Journal of International Sport Sciences 2 (1), $1-11$.

[18] Yildıran, I., (1992). Historical dimensions of the concept of fair play in sport, Hacettepe University Sports Sciences II. National Congress, Ankara.

[19] Vidoni, C., Ward, P. (2009). Effects of fair play instruction on student social skills during a middle school sport education unit. Physical Education and Sport Pedagogy, 14(3), 285-310.

[20] Pilz, G. A. (1995). Performance sport: Education in fair play? (Some empirical and Theoretical remarks). International Review for the Sociology of Sport, 30(3-4), 391-418.

[21] Gessmann, R. (1995). Fair Play- Eine wichtige Erziehungsaufgabe und ihre Umsetzung im Sportunterricht", Fairness und Fair Play, Hrsg.: Volker Gerhardt; Manfred Laemmer, 1. Aufl., Sankt Augustin: Academia-Verlag.

[22] Comeron, M. (2002). The prevention of violence in sport. Strasbourg: Council of Publishing.

[23] Yıldıran, İ. (2005). The role of physical education in fair play. Gazi Journal of Physical Education and Sports Sciences 10(1), 3-16.

[24] Bailey, R. (2006). Physical education and sport in schools: A review of benefits and outcomes. Journal of school health, 76(8), 397-401. 